\title{
Estimating the Health Cost of Air Pollution: The Case of Morocco
}

\author{
Lelia Croitoru*, Maria Sarraf \\ The World Bank Group, Washington D.C., USA \\ Email: *lcroitoru@worldbank.org
}

How to cite this paper: Croitoru, L. and Sarraf, M. (2017) Estimating the Health Cost of Air Pollution: The Case of Morocco. Journal of Environmental Protection, 8, 1087-1099.

https://doi.org/10.4236/jep.2017.810069

Received: August 17, 2017

Accepted: September 17, 2017

Published: September 20, 2017

Copyright $\odot 2017$ by authors and Scientific Research Publishing Inc. This work is licensed under the Creative Commons Attribution International License (CC BY 4.0).

http://creativecommons.org/licenses/by/4.0/

(c) () Open Access

\begin{abstract}
Globally, ambient fine particulate matter $\left(\mathrm{PM}_{2.5}\right)$ is the fifth leading cause of death. Household air pollution from use of solid fuels is the tenth ranked cause of death. Together, ambient and household air pollution caused 6.4 million deaths worldwide. In the Middle East and North Africa region, an estimated 125,000 lives are lost annually to diseases associated with ambient and household air pollution. This paper estimates the economic cost of air pollution in Morocco, a country marked by rapid economic development and urbanization. Using the most updated causal relationships between long-term exposure to $\mathrm{PM}_{2.5}$ and premature mortality, the paper estimates that air pollution costs society about US $\$ 1.14$ billion annually, or 1.05 percent of the country's GDP in 2014. Ambient air pollution is responsible for nearly three quarters of this cost, as a result of large exposure to high $\mathrm{PM}_{2.5}$ levels in cities like Casablanca, Tangier, and Marrakesh. Household air pollution is a problem particularly for rural households using solid fuels for cooking and heating. Based on these results, the paper identifies the most affected areas and the most vulnerable groups in the country.
\end{abstract}

\section{Keywords}

Ambient Air Pollution, Household Air Pollution, Mortality, Morbidity, $\mathrm{PM}_{2.5}$

\section{Introduction}

Ambient air pollution ${ }^{1}$ is a major contributor to human mortality and morbidity [1] [2] [3]. Epidemiological studies have established robust causal relationships between long-term exposure to $\mathrm{PM}_{2.5}$ - particulate matter with aerodynamic diameter of less than 2.5 microns-and premature deaths related to heart dis${ }^{1}$ This paper uses the World Health Organization (WHO) terminology of ambient (outdoor) air pollution (http://www.who.int/mediacentre/factsheets/fs313/en/) and household (indoor) air pollution (http://www.who.int/indoorair/en/) 
ease, stroke, respiratory diseases, and lung cancer, thereby substantially reducing life expectancy [4]. Exposure to $\mathrm{PM}_{2.5}$ also causes morbidity, resulting in problems such as cases of chronic bronchitis, hospital admissions, work loss days, restricted activity days, and acute lower respiratory infections in children [5].

In 2015, ambient $\mathrm{PM}_{2.5}$ was the fifth-ranked mortality risk factor ${ }^{2}$, accounting for 7.6 percent of total global mortality [6], causing 4.2 million deaths and 103.1 million lost years of healthy life [7]. Ischemic heart disease and cerebro-vascular diseases accounted for 57 percent of the deaths. China and India stood out with the highest air pollution-related mortality, each exceeding 1 million deaths. In addition, globally, household air pollution from the use of solid fuels (e.g. coal, wood, dung) for cooking and heating was the tenth-ranked mortality risk factor in 2015, being responsible for 2.8 million deaths and 85.6 million lost years of healthy life [6] [7].

Recent efforts estimated that premature mortality cost the global economy about US $\$ 225$ billion in lost labor income in 2013, or about US\$5.1 trillion in welfare losses [8]. In the Middle East and North Africa region, an estimated 125,000 lives were lost in the same year to diseases associated with ambient and household air pollution; this corresponded to welfare losses of about US $\$ 154$ billion, or 2.2 percent of the regional gross domestic product (GDP).

This paper estimates the economic cost of air pollution in Morocco. It is part of a broader study carried out by the World Bank, which aims to estimate the overall cost of environmental degradation in the country [9]. The paper uses the most updated methodology to value in monetary terms the impact of $\mathrm{PM}_{2.5}$ on people's health; puts the results into a broader perspective of the country's overall cost of environmental degradation; and identifies the most affected areas and groups in Morocco. The analysis has been carried out during 2015-2016, and is based on secondary information collected from Government institutions, national statistics and scientific literature.

\section{Air Pollution in Morocco}

Between 2004 and 2014, Morocco experienced strong economic growth, reflected by an overall increase in per capita GDP of 34 percent [10]. During the same period, population grew by an annual 1.25 percent on average; while urban population, which is mostly concentrated on coastal areas, increased even faster (2.1 percent per year) [11]. Coastal cities are also home for most economic activities, such as energy and industry, and have experienced a rapid growth of road traffic [12]. These activities generated a rapid increase in emissions of local and global air pollutants [13].

Ambient air pollution. The country started to monitor air quality in 1997.The first efforts were carried out by the Ministry of Sustainable Development in the city of Rabat using a mobile laboratory, and were followed by measurements conducted by the Directorate of National Meteorology (Direction de

${ }^{2}$ After high systolic blood pressure, smoking, high fasting plasma glucose and high total cholesterol. 
la météorologienationale, DMN) in Greater Casablanca. Currently, the DMN manages the national air quality-monitoring network, which has 29 fixed and 3 mobile stations covering 15 cities [14]. These stations monitor the ambient concentration of several particulates, such as nitrogen dioxide $\left(\mathrm{NO}_{2}\right)$, particulate matter with diameter less than 10 microns $\left(\mathrm{PM}_{10}\right)$, ozone $\left(\mathrm{O}_{3}\right)$, and carbon monoxide (CO). Aware of the harmful effects of local pollutants on people's health, the country has already conducted several studies which valued the impacts of ambient air pollution on people's health in Casablanca, Mohammedia, and Fès [15] [16].

Household air pollution resulting from the use of solid fuels for cooking and heating is also associated with substantial health effects [4]. Generally, burning solid fuels (wood, charcoal, agricultural residues) in households causes emissions of $\mathrm{PM}_{2.5}$ and other pollutants harmful to human health. Other fuels (e.g. liquefied petroleum gas, biogas) are cleaner and generate less $\mathrm{PM}_{2.5}$. In Morocco, no information is available on $\mathrm{PM}_{2.5}$ concentrations at the level of rural households. However, per capita energy consumption was estimated at 0.54 tons of oil equivalent (toe) in 2012, which is very low compared to the world average (1.9 toe/capita) and that of Africa (0.67 toe/inhabitant) [17]. Wood and coal accounted for 25 percent of total energy consumption in the same year, according to communications with the Department of Energy and Mines ${ }^{3}$.

\section{Ambient Air Pollution}

This section estimates the impact of exposure to ambient $\mathrm{PM}_{2.5}$ on human mortality and morbidity, using 2014 as the year of reference. The valuation is based on four steps, presented below.

Step 1. Measure the $\mathrm{PM}_{2.5}$ concentration. The Ministry of Sustainable Development monitors only particles with a diameter of less than 10 micrometers $\left(\mathrm{PM}_{10}\right)^{4}$. Several measurement stations located in Agadir, Benslimane, Casablanca, El Jadida, Fès, Mohammedia, Khouribga, Marrakech, Safi, Salé, and Tangier provided daily data for the period 2012-2015. These data are used to estimate the annual average $\mathrm{PM}_{2.5}$ concentrations for each city, as follows:

1) The annual average $\mathrm{PM}_{10}$ concentration for each station is quantified based on daily monitoring data.

\footnotetext{
${ }^{3}$ According to communications with the Department of Energy and Mines, energy consumption in rural areas in 2012 was based on butane (788 toe), wood and charcoal (339 toe) and electricity (186 toe). It is important to note that the country's energy sector grew considerably, particularly in the electricity sector. Nowadays, all cities are connected to the network of the National Office of Water and Electricity and the rate of rural electrification is 96.8 percent. In addition, the National Energy Strategy-based on the mobilization of its own national resources and the growth of renewable energies in the energy mix-places Morocco among the leading countries in terms of renewable energy development [17].

${ }^{4} \mathrm{~A}$ global effort has been conducted to estimate the trend in ambient $\mathrm{PM}_{2.5}$ concentrations in each country [18], based on a combination of satellite imagery and ground-based $\mathrm{PM}_{2.5}$ observations. However, this paper uses data from ground measurements, as they are considered to be more reliable. For example, for the city of Casablanca, the annual $\mathrm{PM}_{2.5}$ concentration was estimated at 12.3 $\mu \mathrm{g} / \mathrm{m}^{3}$, based on satellite data, as opposed to $19 \mu \mathrm{g} / \mathrm{m}^{3}$, based on ground measurements [9].
} 
2) For each station, the annual $\mathrm{PM}_{10}$ concentration is converted to $\mathrm{PM}_{2.5}$ concentration, using a conversion factor of 0.4 [19].

3) At the city level, $\mathrm{PM}_{2.5}$ concentration is estimated as the average of concentration data provided by all measuring stations located in that city. For the largest cities (Casablanca and Marrakech), the annual $\mathrm{PM}_{2.5}$ concentration is estimated as a population-weighted average of the $\mathrm{PM}_{2.5}$ concentration at each station.

The results indicate that average $\mathrm{PM}_{2.5}$ concentrations vary widely, from 3 $\mu \mathrm{g} / \mathrm{m}^{3}$ in Safi to as high as $22 \mu \mathrm{g} / \mathrm{m}^{3}$ in Tangier (Table 1 ).

The following steps estimate the health impacts for the cities with $\mathrm{PM}_{2.5}$ concentrations above the World Health Organization (WHO) air quality standard ${ }^{5}$ of $10 \mu \mathrm{g} / \mathrm{m}^{3}$. These are Tangier, Marrakech, Casablanca, Mohammedia, Settat, Fès, Benslimane, and Khouribga.

Step 2. Estimate the population exposed to $\mathbf{P M}_{2.5}$. Data on the percentage of total population exposed to pollution are not available for any monitoring station in Morocco. However, as urban transport generates much of the ambient air pollution, the paper assumes that the entire population of each city is affected by the average $\mathrm{PM}_{2.5}$ concentration calculated at the previous step (Table 1).

Step 3. Quantify the health impacts of exposure to $\mathbf{P M}_{2.5}$. Several epidemiological studies revealed strong correlations between long-term exposure to $\mathrm{PM}_{2.5}$ and premature mortality [20] [21] [22] [23] [24]. In particular, recent research associated $\mathrm{PM}_{2.5}$ exposure with mortality related to four diseases in adults

Table 1. Population and $\mathrm{PM}_{2.5}$ concentration in the main Moroccan cities.

\begin{tabular}{|c|c|c|}
\hline City & $\begin{array}{l}\text { Population } \\
\quad(000)\end{array}$ & $\begin{array}{l}\text { Annual ambient } \mathrm{PM}_{2.5} \\
\text { concentration* }\left(\mu \mathrm{g} / \mathrm{m}^{3}\right)\end{array}$ \\
\hline Tangier & 1,005 & 22 \\
\hline Marrakech & 981 & 20 \\
\hline Casablanca & 3,360 & 20 \\
\hline Mohammedia & 289 & 18 \\
\hline Settat & 218 & 17 \\
\hline Fès & 1,130 & 16 \\
\hline Benslimane & 114 & 13 \\
\hline Khouribga & 378 & 12 \\
\hline Agadir & 508 & 5 \\
\hline El-Jadida & 312 & 4 \\
\hline Salé & 916 & 4 \\
\hline Safi & 346 & 3 \\
\hline
\end{tabular}

Source: [11] for population census, DMN for $\mathrm{PM}_{10}$ concentration per monitoring station (2012-2015). ${ }^{*}$ Estimate based on daily measurements of $\mathrm{PM}_{10}$ concentration.

${ }^{5} \mathrm{An}$ annual average concentration of $10 \mu \mathrm{g} / \mathrm{m}^{3}$ was chosen as the long-term guideline value for $\mathrm{PM}_{2.5}$ (http://www.who.int/phe/health_topics/outdoorair/outdoorair_aqg/en/). This represents the lower end of the range over which significant effects on survival were observed by the American Cancer Society [3]. 
(ischemic heart disease, stroke, chronic obstructive pulmonary disease, and lung cancer) and acute lower respiratory tract infections in children. These relationships, called integrated exposure-response functions, were used to estimate mortality for each health endpoint, age group, and $\mathrm{PM}_{2.5}$ concentration in each city [4]. The results show that ambient air pollution was responsible for about 2,200 deaths in 2014. Nearly 50 percent of adult deaths originate in Casablanca, followed by Marrakesh and Tangier, mainly due to ischemic heart disease, stroke and lung cancer (Figure 1). Overall, more than 70 percent of deaths result from ischemic heart disease and stroke.

Figure 2 presents the distribution of premature mortality estimate by age

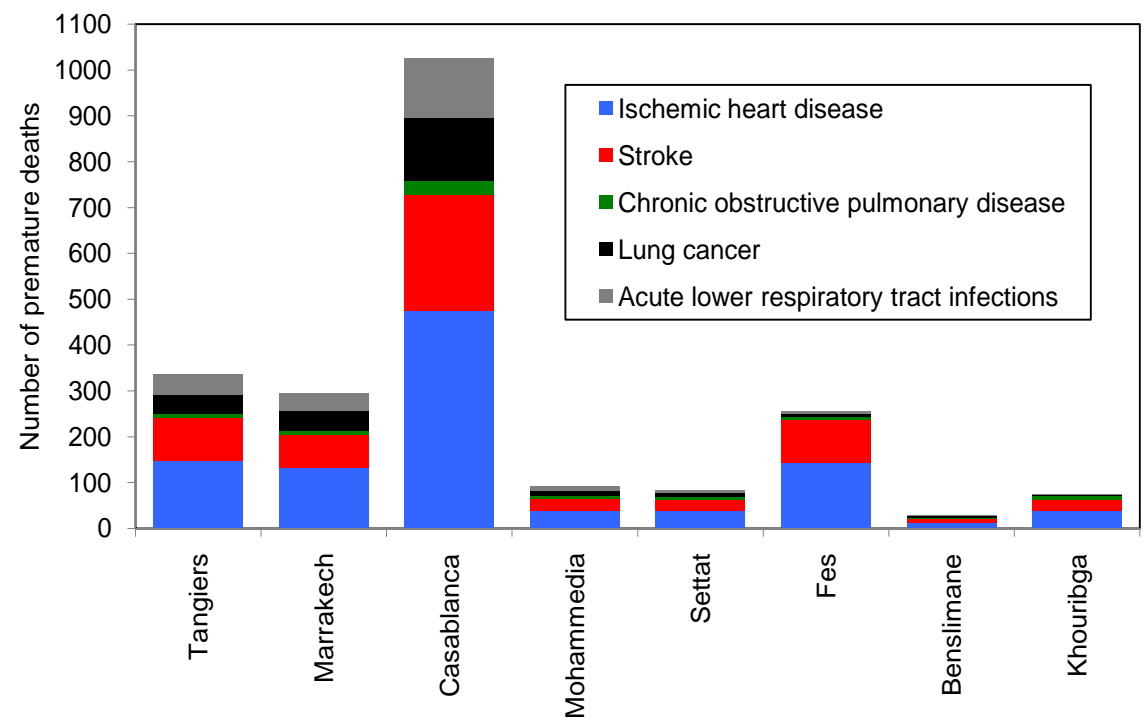

Figure 1. Premature deaths due to $\mathrm{PM}_{2.5}$ exposure by city (2014). Source: authors' calculations.

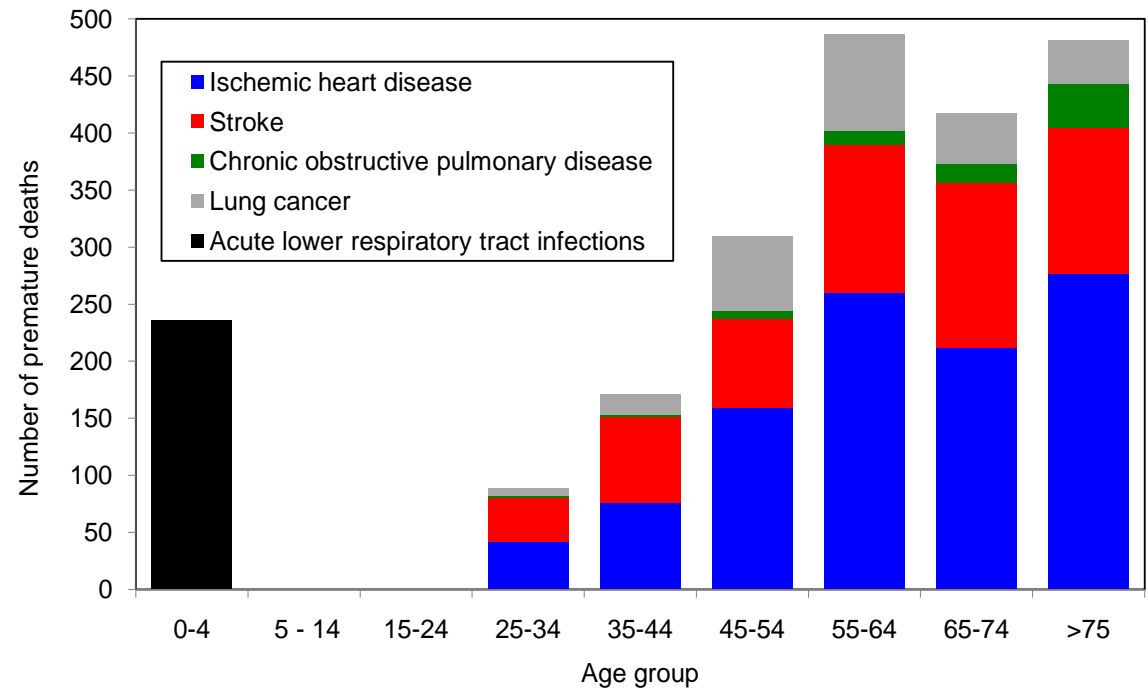

Figure 2. Premature deaths due to exposure to ambient $\mathrm{PM}_{2.5}$, by age (2014). Source: authors' calculations. 
group and disease. Adults over the age of 55 are at risk of premature mortality due mainly to ischemic heart disease and strokes. Children under five years old are also vulnerable to premature mortality due to acute lower respiratory tract infection.

It should be noted that the Institute of Health Metrics and Evaluation (IHME) has estimated mortality in Morocco at 6,000 deaths for the same year, based on a combination of ground and satellite measurements of $\mathrm{PM}_{2.5}$ ambient concentration (http://ihmeuw.org/3ts8). Two reasons explain the difference in results: (i) the IHME estimates cover the whole country, while the above estimate is conducted for eight cities only; and (ii) the IHME estimates are partly based on satellite data, which are less accurate than ground-based measurements. Therefore, this paper considers mortality in Morocco to be in the range provided by the two estimates, namely between 2,200 and 6,000 deaths.

Step 4. Estimate the health impacts of exposure to $\mathrm{PM}_{2.5}$. The cost of mortality is estimated based on the concept of the Value of Statistical Life (VSL). It has been widely used in environmental economics literature to reflect people's willingness to pay for a reduction in mortality risk [8] [25] [26]. The VSL for Morocco was estimated at about US $\$ 191,500$ (Box 1). Accordingly, the cost of premature mortality (between 2,200 and 6,000) caused by ambient air pollution ranges between US $\$ 420$ million and US\$1.15 billion (a).

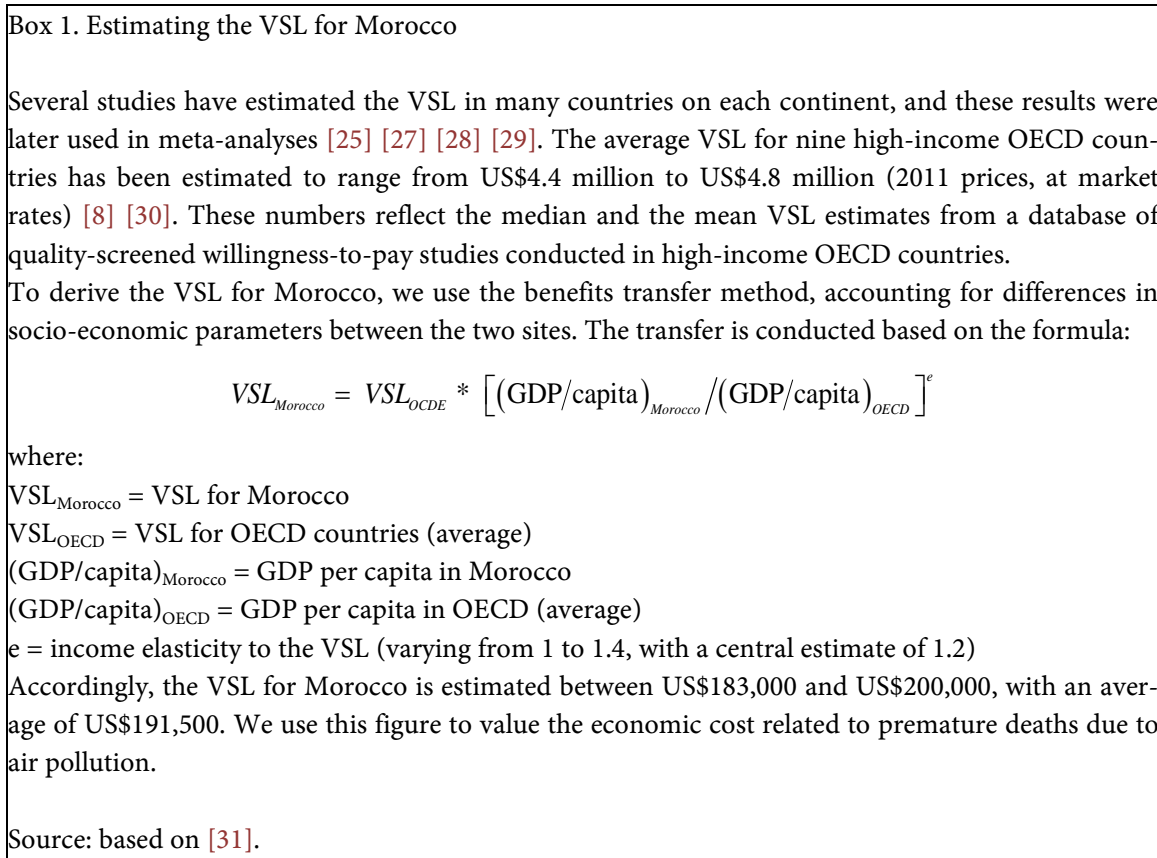

The cost of morbidity includes resource costs (i.e. financial costs for avoiding, protecting, or treating pollution-associated illnesses), opportunity costs (i.e. indirect costs from the loss of time for work and leisure), and disutility costs (i.e. cost of pain, suffering, or discomfort). The literature assessing causal relationships between exposure to $\mathrm{PM}_{2.5}$ and morbidity is much more limited than that 
for mortality ${ }^{6}$ [5]. So far, no commonly accepted method has been developed to value the overall cost of morbidity due to air pollution [32] $]^{7}$.

However, results of studies conducted in several OECD countries indicate that morbidity costs can be roughly approximated to 10 percent of mortality costs [5] [30] [32] [33]. In the absence of surveys on the willingness to pay to avoid pollution-related illnesses in Morocco, morbidity costs are estimated at 10 percent of mortality costs, i.e. between US\$42 million and US\$115 million (b).

Adding up the costs of mortality and morbidity $(a+b)$, the total loss due to ambient air pollution ranges between US\$462 million and US\$1.26 billion, with an average of US\$863 million (Table 2).

\section{Household Air Pollution}

This section estimates the cost of household air pollution, through the impact of using solid fuel for cooking and heating in rural households. A similar step-by-step approach is used:

Step 1. Measure $\mathrm{PM}_{2.5}$ concentration. $\mathrm{PM}_{2.5}$ concentrations in rural households using solid fuel for cooking vary considerably, depending on the location of the kitchen (e.g. indoors or outdoors), method and duration of cooking, ventilation practices, etc. Concentrations of $\mathrm{PM}_{2.5}$ often reach several hundred $\mu \mathrm{g} / \mathrm{m}^{3}$

Table 2. Health cost of air pollution (US\$ million*, 2014).

\begin{tabular}{ccccc}
\hline & Lower bound & Higher bound & Average & \% of GDP \\
\hline Mortality & 420 & 1,149 & 784 & 0.71 \\
Morbidity & 42 & 115 & 78 & 0.07 \\
Sub-total (ambient) & 462 & 1,264 & 863 & 0.79 \\
\hline Household air pollution & & & & \\
Mortality & 248 & 271 & 259 & 0.24 \\
Morbidity & 25 & 27 & 26 & 0.02 \\
Sub-total (household) & 273 & 298 & 285 & 0.26 \\
\hline Total health cost & 734 & 1,562 & 1,148 & 1.05 \\
\hline
\end{tabular}

Source: authors' calculation. Note: ${ }^{\star}$ except for the last column. The totals may not add up exactly due to rounding.

${ }^{6}$ Valuing morbidity is complicated due to several issues: it involves multiple health endpoints suffered by a variety of agents (patient, friends, family, coworkers, etc.); missing data on health expenditures and medical treatment costs for many countries; differences among countries in health care systems and how heath care costs are allocated to patients, care providers, and the public treasury; few studies of willingness to pay to avoid different kinds of illnesses and other medical conditions associated with pollution exposure.

${ }^{7}$ Several methods were used in the past to estimate the burden of disease caused by environmental risks, based on Disability Adjustment Life Years (DALYs) concept, as well as the cost of illness, in terms of treatment costs. 
in the kitchen and more than $100 \mu \mathrm{g} / \mathrm{m}^{3}$ in the rest of the household ${ }^{8}$.

No measure of $\mathrm{PM}_{2.5}$ concentration was found for Morocco's rural households; however, the WHO has compiled a global database of 154 studies on measures of household air pollution. Although the database does not provide $\mathrm{PM}_{2.5}$ concentrations in any North African country, it contains a few relevant results. For example, [34] report indoor $\mathrm{PM}_{2.5}$ concentrations in some areas of India ranging from about $160 \mu \mathrm{g} / \mathrm{m}^{3}$ in living areas to about $600 \mu \mathrm{g} / \mathrm{m}^{3}$ in kitchens; and [35] measured concentrations of approximately $100 \mu \mathrm{g} / \mathrm{m}^{3}$ in outdoor terraces with open fire cooking in rural Mexico following adoption of improved wood stoves. As wood stoves or ovens are widely used in Morocco for cooking [36], this paper conservatively assumes an annual average $\mathrm{PM}_{2.5}$ concentration of $100 \mu \mathrm{g} / \mathrm{m}^{3}$ in rural households that use solid fuel for cooking.

Step 2. Estimate the population exposed to $\mathbf{P M}_{2.5}$. Household exposure to $\mathrm{PM}_{2.5}$ emitted by combustion of solid fuels depends on the activity patterns inside the household. A recent study [17] indicated that 20 percent of rural households used wood for cooking in 2010 and projected a reduction to 5 percent by 2040. Applying this trend over time resulted in about 18 percent of rural households using wood for cooking in 2014. Applying this proportion to the total rural population of 13.4 million [11], the total population exposed to household $\mathrm{PM}_{2.5}$ is estimated at 2.4 million people in 2014.

Step 3. Estimate the health impacts of exposure to $\mathbf{P M}_{2.5}$. The same integrated exposure-response functions are applied as in Section 3. The results show that household air pollution was responsible for about 1,350 deaths in 2014, of which nearly 90 percent are caused by ischemic heart disease, stroke, or acute lower respiratory tract infections. Figure 3 shows that the oldest (over 55 years) and the youngest (less than 5 years old) are the groups most affected by household air pollution.

Step 4. Estimate the health impacts of exposure to $\mathrm{PM}_{2.5}$. Using a VSL of US $\$ 191,500$ (Box 1), the cost of premature mortality (1,350 deaths) caused by household air pollution is estimated to be between US $\$ 248$ million and US $\$ 271$ million. In addition, morbidity costs are valued at 10 percent of mortality cost, i.e. between US $\$ 25$ million and US $\$ 27$ million. Adding these values, the total health cost due to household air pollution ranges between US $\$ 273$ million and US\$298 million, with an average of US\$285 million (Table 2).

\section{Total Health Cost of Air Pollution}

The total health cost of air pollution is estimated between US\$734 million and US $\$ 1.6$ billion. This corresponds to an average of US $\$ 1.14$ billion, or 1.05 percent of the country's GDP in 2014 (Table 2). Ambient air pollution dominates the total cost (75 percent of the total), primarily as a result of high exposure to

${ }^{8} \mathrm{WHO}$ indoor air pollution database:

http://www.who.int/indoorair/health_impacts/databases_iap/en/ 


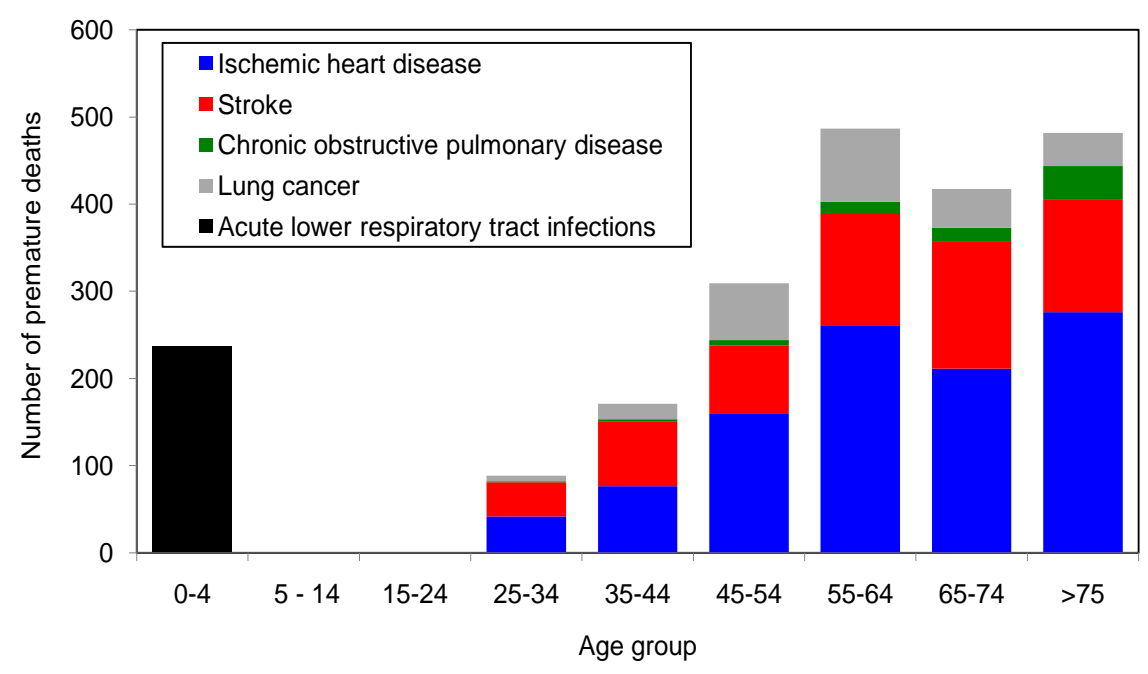

Figure 3. Premature deaths due to household $\mathrm{PM}_{2.5}$ exposure by age (2014). Source: authors' calculation.

ambient $\mathrm{PM}_{2.5}$ in urban areas such as Casablanca, Tangier, and Marrakesh. Household air pollution is a significant problem for the 18 percent of the rural households that use solid fuel for cooking.

It should be noted that the above estimates are subject to several limitations. From a methodological point of view, mortality estimates refer only to the impacts of $\mathrm{PM}_{2.5}$ on five respiratory diseases, for which robust causal relationships have been established in the literature; while those related to morbidity are not correlated with any specific diseases. From an empirical viewpoint, data related to household air pollution are either lacking (e.g. indoor $\mathrm{PM}_{2.5}$ concentration) or partial (e.g. types of stoves and cooking practices), which imposed reliance on information from other areas.

This analysis is part of a broader study conducted by the World Bank, which estimated the overall cost of environmental degradation in Morocco [9]. It addressed the degradation related to several natural resources (categories): water, air, agricultural land, waste management, coastal zones, and forests. The results showed that the total cost of environmental degradation was about 3.52 percent of the country's GDP in 2014. Air pollution was found to be the second most important type of degradation in the country, after water overexploitation and pollution (Figure 4).

\section{Conclusions}

The paper points to the following key conclusions:

- The health impacts from $\mathrm{PM}_{2.5}$ exposure is a pressing environmental challenge in the country, costing society US $\$ 1.14$ billion, or 1.05 percent of the country's GDP in 2014. In relative terms, the results are lower than those obtained in other countries of the region (3.58 percent of Egypt's GDP; 2.48 percent of Iran's GDP), and in the region as a whole (2.2 percent of the 


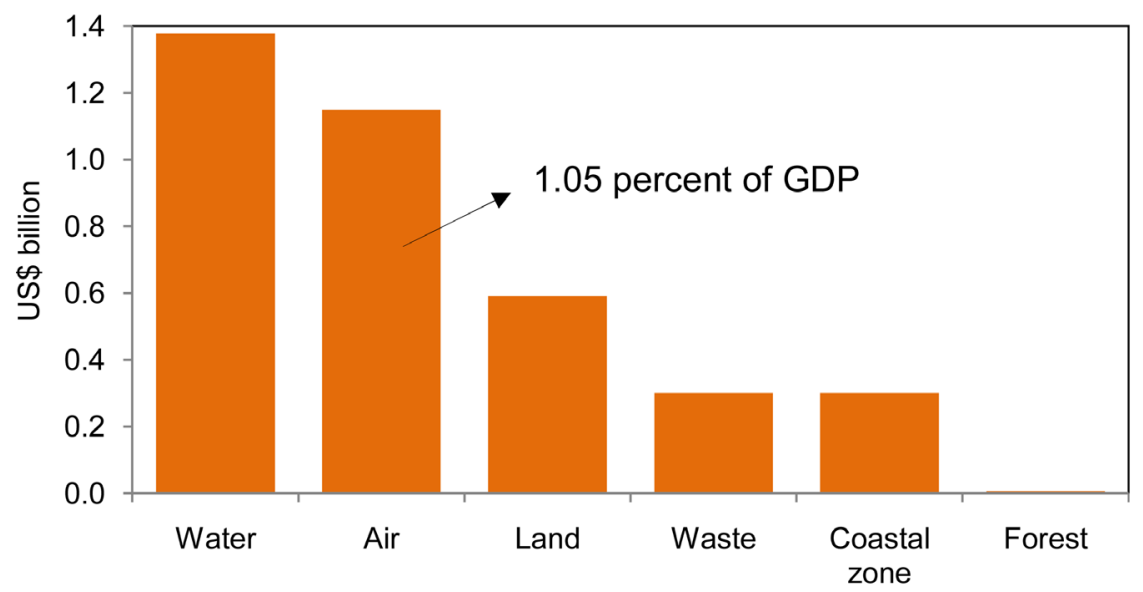

Figure 4. Total cost of environmental degradation in Morocco (2014). Source: based on [9].

Middle East and North Africa's regional GDP) ${ }^{9}$ [8].

- Exposure to $\mathrm{PM}_{2.5}$ caused an estimated 5,450 deaths on average, of which about 75 percent are due to ambient air pollution and 25 percent are due to household air pollution. The cost of ambient air pollution is particularly high in cities like Casablanca, Tangier, and Marrakesh, due to large populations exposed to high levels of $\mathrm{PM}_{2.5}$ concentration. At the same time, household air pollution is a significant problem for the 18 percent of the rural households that use wood and coal for cooking and heating.

- The most vulnerable groups for premature deaths from air pollution are adults over 55 years old (due to ischemic heart disease and stroke) and children under 5 (due to acute lower respiratory infections). Special attention should be targeted to these age groups when designing programs for reducing health impacts from air pollution.

Morocco has made considerable progress in establishing air pollution monitoring systems in several urban areas. It is important to continue the assessment and analysis of ambient data by taking into account the expansion of cities and the industrial sites [37]; as well as to conduct monitoring of household air pollution in key rural areas where use of solid fuels for cooking and heating is common. Concrete options to reduce the cost of ambient air pollution should first be implemented in the most affected cities: Casablanca, Tangier, Marrakesh. Existing studies indicate several ways of reducing ambient pollution, depending on the source. For example, air pollution from the transport sector can be decreased through transport system improvements (e.g. improving public transportation, encouraging alternative modes of transport-including non-motorized transport, improving traffic management) and through vehicle level improvement (e.g. improving fuels and technology) [38]. These options, as well as others, need to be carefully considered and tailored to the context of each city, in order to

${ }^{9}$ It should be noted that it is difficult to directly compare the above estimates, due to differences in sources of data (e.g. satellite imagery, ground measurements), years of reference, etc. 
achieve healthier lives and better economic opportunities.

\section{Acknowledgements}

This paper is a result of a broader analytical work carried out by the World Bank, which estimated the cost of environmental degradation in Morocco. The authors gratefully acknowledge the support of the Ministry of Sustainable Development in Morocco, in particular Ms. R. Chafil, Mr. M. Maktit and Mr. S. Maliki, as well as the contribution of the Directorate of National Meteorology and the Ministry of Health. Special thanks are given also to Ms. E. Strukova, Mr. C. Sall, Mr. A. Khattabi, Mr. A. Jorio, and M. S. Belghazi for their support.

\section{References}

[1] Brook, R.D., Rajagopalan, S., Pope, C.A., Brook, J.R., Bhatnagar, A., Diez-Roux, A.V., Holguin, F., Hong, Y., Luepker, R.V., Mittleman, M.A., Peters, A., Siscovick, D., Smith, S.C., Jr. Whitsel, L., Kaufman, J.D. (2010) Particulate Matter Air Pollution and Cardiovascular Disease: An Update to the Scientific Statement from the American Heart Association. Circulation, 121, 2331-2378. https://doi.org/10.1161/CIR.0b013e3181dbece1

[2] Pope, C.A. and Dockery, D.W. (2006) Health Effects of Fine Particulate Air Pollution: Lines That Connect. Journal of the Air and Waste Management Association, 56, 709-742. https://doi.org/10.1080/10473289.2006.10464485

[3] Pope, C.A., Burnett, R.T., Thun, M.J., Calle, E.E., Krewski, D., Ito, K. and Thurston, G.D. (2002) Lung Cancer, Cardiopulmonary Mortality, and Long-Term Exposure to Fine Particulate Air Pollution. JAMA, 287, 1132-1141.

https://doi.org/10.1001/jama.287.9.1132

[4] Apte, J.S., Marshall, J.D., Cohen, A.J. and Brauer, M. (2015) Addressing Global Mortality from Ambient $\mathrm{PM}_{2.5}$. Environmental Science and Technology, 49, 8057-8066. https://doi.org/10.1021/acs.est.5b01236

[5] Hunt, A., Ferguson, J., Hurley, F. and Searl, A. (2016) Social Costs of Morbidity Impacts of Air Pollution, OECD Environment Working Papers, No. 99, OECD Publishing, Paris.

[6] Institute for Health Metrics and Evaluation and the Health Effects Institute (IHME and HEI) (2017) State of Global Air. A Special Report on Global Exposure to Air Pollution and Its Disease Burden. https://www.stateofglobalair.org/sites/default/files/SOGA2017_report.pdf

[7] Cohen, A., Brauer, M., Burnett, R., Anderson, H.R., Frostad, J., Estep, K., Balakrishnan, K., Brunekreef, B., Dandona, L., Dandona, R., Feigin, V., Freedman, G., Hubbell, B., Joblin, A., Kan, H., Knibbs, L., Liu, Y., Martin, R., Morawska, L., Pope, C.A., Shin, H., Straif, K., Shaddick, G., Thomas, M., van Dingenen, R., Donkelaar, A., Vos, T., Murray, C.J.L. and Forouzanfar, M.H. (2017) Estimates and 25-Year Trends of the Global Burden of Disease Attributable to Ambient Air Pollution: An Analysis of Data from the Global Burden of Diseases Study 2015. The Lancet, 389, 1907-1918. https://doi.org/10.1016/S0140-6736(17)30505-6

[8] World Bank and Institute for Health Metrics and Evaluation (2016) The Cost of Air Pollution. Strengthening the Economic Case for Action. The World Bank, Washington D.C.

[9] Croitoru, L. and Sarraf, M. (Eds.) (2017) Le Coût de la Dégradation de l'Environnement au Maroc. Environment and Natural Resources Global Practice Discussion Paper \#5. 
World Bank Group Report Number 105633-MA. Washington D.C.

[10] World Bank (2015) World Development Indicators. World Bank, Washington D.C.

[11] Haut Commissariat au Plan (2015) Recensement général de la population et de l'habitat. [General Census of Population and Housing.] Présentation des principauxrésultats. http://www.hcp.ma

[12] United Nations Economic Commission for Europe (2014) Morocco. Environmental Performance Review. United Nations.

[13] Ministry of Environment (2015) Report on the State of the Environment in Morocco. Ministry Delegated to the Minister of Energy, Mines, Water and Environment.

[14] Direction de la météorologie nationale (2014) Rapport national sur la qualité de l'air au Maroc. [National Report on Air Quality in Morocco.] Direction de la météorologie nationale.

[15] Ministry of Environment (2010) Étude relative à l'élaboration du programme national de lutte contre la pollution atmosphérique. Mission I: Analyse de l'existant. [Study on the Development of the National Program of Air Pollution Control. Mission I: Analysis of the Current Situation.] Rapport définitif.

[16] Ministry of Health (2015) Etude eco-épidémiologique "Qualite de l'air et santé dans la region du Grand Casablanca". [Eco-Epidemiological Study on Air Quality and Health in the Region of Greater Casablanca.] Rapport Mai 2015.Ministry of Health.

[17] Ministry of Environment/United Nations Development Programme (2015) Mission II. Évaluation des programmes comportant des mesures visant à atténuer les émissions des gaz à effet de serre, 77. [Mission II. Evaluation of Programs of Measures Aimed at Mitigating Emissions of Greenhouse Gases.]

[18] Van Donkelaar, A., Martin, R.V., Brauer, M. and Boys, B.L. (2015) Use of Satellite Observations for Long-Term Exposure Assessment of Global Concentrations of Fine Particulate Matter. Environmental Health Perspectives, 123, 135-143.

[19] Ait Bouh, H., Benyaich, F., Bounakhla, M., Noack, Y., Tahri M. and Zahry, F. (2013) Seasonal Variations of the Atmospheric Particles and Its Chemical Components in Meknes City-Morocco. Journal of Materials and Environmental Science, 4, 49-62.

[20] Pope III, C.A., Burnett, R.T., Krewski, D., et al. (2009) Cardiovascular Mortality and Exposure to Airborne Fine Particulate Matter and Cigarette Smoke: Shape of the Exposure-Response Relationship. Circulation, 120, 941-948.

https://doi.org/10.1161/CIRCULATIONAHA.109.857888

[21] Pope III, C.A., Burnett, R.T., Turner, M.C., Cohen, A., Krewski, D., Jerrett, M., Gapstur, S.M. and Thun, M.J. (2011) Lung Cancer and Cardiovascular Disease Mortality Associated with Ambient Air Pollution and Cigarette Smoke: Shape of the Exposure-Response Relationships. Environmental Health Perspectives, 119, 1616-1621. https://doi.org/10.1289/ehp.1103639

[22] Lim, S.S., Vos, T., Flaxman, A.D., Danaei, G., et al. (2012) A Comparative Risk Assessment of Burden of Disease and Injury Attributable to 67 Risk Factors and Risk Factor Clusters in 21 Regions, 1990-2010: A Systematic Analysis for the Global Burden of Disease Study 2010. Lancet, 380, 2224-2260. https://doi.org/10.1016/S0140-6736(12)61766-8

[23] Mehta, S., Shin, H., Burnett, R., North, T. and Cohen, A. (2013) Ambient Particulate Air Pollution and Acute Lower Respiratory Infections: A Systematic Review and Implications for Estimating the Global Burden of Disease. Air Quality, Atmosphere and Health, 6, 69-83. https://doi.org/10.1007/s11869-011-0146-3

[24] Krewski, D., Jerrett, M., Burnett, R.T., Ma, R., Hughes, E., Shi, Y., Turner, M.C., Pope, C.A., Thurston, G., Calle, E.E., Thun, M.J., Beckerman, B., De Luca, P., Finkelstein, N., Ito, K., Moore, D.K., Newbold, K.B., Ramsay, T., Ross, Z., Shin, H. and 
Tempalski, B. (2009) Extended Follow-Up and Spatial Analysis of the American Cancer Society Study Linking Particulate Air Pollution and Mortality. Research Report 140, Boston, MA. https://doi.org/10.1111/j.1539-6924.2011.01694.x

[25] Lindhjem, H., Navrud, S. and Axel Braathen, N. (2011) Valuing Lives Saved from Environmental, Transport and Health Policies: A Meta-Analysis of Stated Preference Studies. Risk Analysis, 31, 1381-1407.

https://doi.org/10.1016/j.ecolind.2010.12.006

[26] Desaigues, B., Amia, D., Bartczak, A., Braun-Kohlová, M., Chiltond, S., Czajkowski, M., Farreras, V., Hunt, A., Hutchison, M., Jeanrenaud, C., Kaderjak, P., Mácac, V., Markiewicz, O., Markowska, A., Metcalf, H., Navrud, S., Nielsenj, J.S., Ortizf, R., Pellegrini, S., Rabl, A., Riera, R., Scasny, M., Stoeckel, M.-E., Szántó, R. and Urban, J. (2011) Economic Valuation of Air Pollution Mortality: A 9-Country Contingent Valuation Survey of Value of a Life Year (VOLY). Ecological Indicators, 11, 902-910.

[27] Biausque, V. (2012) The Value of Statistical Life: A Meta-Analysis. OECD ENV/ EPOC/WPNEP(2010)9/FINAL.

[28] Bellavance, F., Dionne, G. and Lebeau, M. (2009) The Value of Statistical Life: A Meta-Analysis with a Mixed Effects Regression Model. Journal of Health Economics, 28, 444-464. https://doi.org/10.1016/j.jhealeco.2008.10.013

[29] Navrud, S. and Lindhem, H. (2011) Valuing Mortality Risk Reductions in Regulatory Analysis of Environmental, Health and Transport Policies: Policy Implications. OECD.ENV/EPOC/WPIEEP(2011)8/FINAL.

[30] Organization for Economic Cooperation and Development (2012) Mortality Risk Valuation in Environment, Health and Transport Policies. OECD Publishing, Paris.

[31] Sall, C. (2015) Deriving a Value of Statistical Life for Morocco in 2014. World Bank Internal Paper, Washington DC.

[32] Organization for Economic Cooperation and Development (2014) The Cost of Air Pollution: Health Impacts of Road Transport. OECD Publishing, Paris.

[33] Narain, U. and Sall, C. (2016) Methodology for Valuing the Health Impacts of Air Pollution. Discussion of Challenges and Proposed Solutions. World Bank, Washington DC.

[34] Balakrishnan, K, Ghosh, S., Ganguli, B., Sambandam, S., Bruce, N., Barnes, D.F. and Smith, K.R. (2013) State and National Household Concentrations of $\mathrm{PM}_{2.5}$ from Solid Cookfuel Use: Results from Measurements and Modeling in India for Estimation of the Global Burden of Disease. Environmental Health, 12, 77-90. https://doi.org/10.1186/1476-069X-12-77

[35] Zuk, M., Rojas, L., Blanco, S., Serrano, P., Cruz, J., Angeles, F., Tzintzun, G., Armendariz, C., Edwards, R.D., Johnson, M., Riojas-Rodriguez, H. and Masera, O. (2007) The Impact of Improved Wood-Burning Stoves on Fine Particulate Matter Concentrations in Rural Mexican Homes. Journal of Exposure Science and Environmental Epidemiology, 17, 224-232. https://doi.org/10.1038/sj.jes.7500499

[36] Atouk, S. (2013) Les énergies renouvelables et les populations rurales pauvres: Le cas du Maroc. [Renewable Energy and the Rural Poor: The Case of Morocco.] Maîtrise en environnement, Universite de Sherbrooke, Quebec.

[37] Chirmata, A., Leghrib, R. and Ichou, I. (2017) Implementation of the Air Quality Monitoring Network at Agadir City in Morocco. Journal of Environmental Protection, 8, 540-567. https://doi.org/10.4236/jep.2017.84037

[38] Gwilliam, K., Kojima, M. and Johnson, T. (2004) Reducing Air Pollution from Urban Transport. The World Bank, Washington DC. 
Submit or recommend next manuscript to SCIRP and we will provide best service for you:

Accepting pre-submission inquiries through Email, Facebook, LinkedIn, Twitter, etc. A wide selection of journals (inclusive of 9 subjects, more than 200 journals)

Providing 24-hour high-quality service

User-friendly online submission system

Fair and swift peer-review system

Efficient typesetting and proofreading procedure

Display of the result of downloads and visits, as well as the number of cited articles Maximum dissemination of your research work

Submit your manuscript at: http://papersubmission.scirp.org/

Or contact jep@scirp.org 